\title{
Prevalence of Newcastle Disease Virus and Avian Influenza Virus (H7N3) in Poultry at Karachi
}

\section{Amjad Ali Channa ${ }^{1, *}$, Nazeer Hussain Kalhoro², Zaheer Ahmed Nizamani ${ }^{1}$, Ayaz Hussain Mangi², Jamila Soomro ${ }^{1}$ \\ 1Department of Veterinary Pathology, Sindh Agriculture University, Tandojam \\ ${ }^{2}$ Sindh Institute of Animal Health, Karachi}

\section{ABSTRACT}

Background: Poultry is the largest and rapidly growing sector of livestock in Pakistan. It is mainly influenced by viral pathogens such as the Newcastle disease virus (NDV) and Avian influenza virus (H7N3). These viruses cause severe disease in poultry and lead to heavy economic losses throughout the world. The outbreaks of these pathogens have been increased in the last few decades. Therefore, the study about antigenic prevalence is needed to know about the emergence of these pathogenic viruses and to get rid of severe ailments associated with reduced poultry production.

Objectives: To determine the prevalence of Newcastle disease virus (NDV), Avian influenza virus (H7N3) and co-infections in poultry flocks at Karachi.

Methodology: For detection of NDV and H7N3, a total of 200 tracheal swabs were collected and tested through Virus Isolation (V.I); the sample with positive virus isolation were tested through Agar gel precipitation (AGP) and then the RNA was isolated through TRI Reagent, which was further tested through Reverse transcription-polymerase chain reaction (RT-PCR).

Results: The virus isolation showed that $58 \%$ of samples were positive for various viruses. Agar gel precipitation (AGP) revealed that the occurrence of NDV, $\mathrm{H} 7 \mathrm{~N} 3$ and $\mathrm{ND}+\mathrm{H} 7$ were $50 \%, 8 \%$ and $38 \%$, respectively. RT-PCR for $\mathrm{F}$ and $\mathrm{HA}$ gene of NDV and $\mathrm{H} 7 \mathrm{~N} 3$ confirmed the presence of NDV and H7N3 in the poultry.

Conclusion: It is concluded that NDV and H7N3 are circulating in the flocks causing co-infections, therefore it is important to know the field challenge of viruses and to prepare a vaccine of circulating serotype of the virus to mitigate the rate of infection.

\section{Keywords}

Poultry, NDV, H7N3, AGP, Livestock,

$R T-P C R$

Cite this article: Channa AA, Kalhoro NH, Nizamani ZA, Mangi AH, Soomro J. Prevalence of Newcastle Disease Virus and Avian Influenza Virus (H7N3) in Poultry at Karachi. RADS J Biol Res Appl Sci. 2020; 11(1):9-14.

This is an Open Access article distributed under the terms of the Creative Commons Attribution License (http://creativecommons.org/licenses/by/4.0), which permits unrestricted use, distribution, and reproduction in any medium provided the original work is properly cited.

\section{INTRODUCTION}

The poultry sector is an important and major segment of livestock and contributes $26.8 \%$ in total meat production, $5.76 \%$ in agriculture, and $1.26 \%$ in the national GDP of Pakistan ${ }^{1}$. Due to rapid growth in population in urban as well as rural areas, there is a high demand for perishable products like fruits, vegetables, dairy and meat products. In these conditions, consumers like to eat fish and poultry meat which contain an adequate amount of omega 3 and milk hence, considered as a balanced ratio playing a vital role to fulfil protein demand. Livestock shows $3.43 \%$ growth per year and produces $58 \%$ of agriculture and $43 \%$ of total labor $^{2}$. Despite the rapid growth of poultry in Pakistan, it is influenced by many viral infections especially, the Newcastle disease (NDV) virus and Avian influenza virus (AIV) H7N3 causing poor weight gain, respiratory distress and drop in egg production ${ }^{3,4}$.

In recent outbreaks, there is the involvement of more than one viruses that pose a severe complication to control 
infections. To achieve proper prevention of these infections, most poultry producers are using live and inactivated vaccines for many years. Even though live vaccine virus replicates in the respiratory tract and can induce a reaction known as a post-vaccination reaction, however, to achieve the required results, the hyperimmune yolk was developed to protect against viral infections ${ }^{5}$. Despite mixed infections, H7N3 is highly contagious which leads to heavy economic loss. A regular and sudden mutation in these viruses could cause minor antigenic differences between the isolates, likely contributed to decreased vaccine protection and shedding of a virus when the hemagglutinin ( $\mathrm{HA})$ sequences differed by up to $13 \% 6$.

It has been found that Pakistan suffered from a heavy economic loss of about 5.4 billion in 2004-5. These losses are associated with epidemics of circulating serotypes of NDV and AIV. Additionally, the outbreaks of Avian influenza viruses have been increasingly occurring in the last few decades in Asian counties, which leads to the major economic defeat of commercial poultry farming. It has also been reported previously that the infection might be transmitted from infected birds to other healthy birds. However, it has not been reported to have birds to human transmission and no human case has been observed? Meanwhile, in early 2003, avian influenza H7 sub-type caused pandemics in Pakistan in commercial breeder because of inactivated mass vaccination ${ }^{8}$.

The diagnosis and detection of virus circulating in the fields pose a severe problem and has key importance. Since 2003, highly pathogenic avian influenza viruses (HPAIVs) H5N1 have infected poultry as well as humans in more than 62 countries in Asia, Africa and Eurasia which leads to 400 million deaths of birds $s^{9,10,11}$. Research has found that low pathogenic Avian influenza viruses cause infections to wild and captive birds, especially in chickens that may acquire high virulence on infection from one flock to another ${ }^{12}$. However, the poultry industry is the fastest-growing field throughout the world and act as a vehicle for transportation of birds either from peri-urban to urban areas or from one live bird market (LBM) to another, that cause infection and outbreaks of various viral and bacterial disease, specially NDV and H7N3. Likewise, the commercialized poultry is a chain for the movement of live poultry, facilitating the transmission, dissemination of infection and re-infection. Therefore, this study is designed to know the prevalence of avian influenza virus $\mathrm{H} 7$ - subtype and NDV.

\section{MATERIALS AND METHODS}

\section{Collection of Samples and Transportation}

A total of 200 samples including tracheal swabs were collected from suspected birds located in Karachi. Samples were transferred in sterile Eppendorf's containing phosphate-buffered saline, transported to Sindh Institute of Animal Health, Karachi and stored at $-70^{\circ} \mathrm{C}$ for further processing.

\section{Virus Isolation}

The samples (tracheal swabs) collected were mixed gently with $1 \mathrm{ml}$ of normal saline and centrifuged for $10 \mathrm{~min}$ at $10,000 \mathrm{rpm}$. The upper transparent fluid was separated and dispensed in a new Eppendorf which was mixed with streptomycin $(40 \mu / / \mathrm{ml})$. After that, $100 \mu \mathrm{l}$ of fluid was inoculated into 5 Embryonated Chicken Eggs (ECE) of 10 days' age. Moreover, the eggs were placed in an incubator at $37^{\circ} \mathrm{C}$ for $72 \mathrm{hrs}$, candled after $24 \mathrm{hrs}$ and the dead eggs were chilled at $4^{\circ} \mathrm{C}$. The amnioallantoic fluid was collected from dead eggs and tested through rapid Hemagglutination Assay (HA). After rapid HA, the positive samples were tested through Agar gel precipitation (AGP) and confirmed by RT-PCR.

\section{Rapid Haemagglutination Assay}

A volume of $500 \mu \mathrm{l}$ harvested amnioallantoic fluid was placed on a rapid HA plate, 2-3 drops of $7 \%$ chicken RBCs were poured on it and the plate was then incubated at room temperature for $10 \mathrm{~min}$ and shaken slowly. The agglutination of chicken RBCs indicated the presence of a virus, while the absence of agglutination shows a negative sample.

\section{Agar Gel Precipitation Test (AGPT)}

Agar gel precipitation was done as described by Okwor, $2011^{13}$ such as a volume of $10 \mathrm{ml}$ noble agar (1\%) was prepared in distilled water containing $8 \%$ sodium azide and the $\mathrm{pH}$ was adjusted up to $7.2 \pm 0.1$. The agar was then poured into petri dishes and incubated for $24 \mathrm{hrs}$. After that, a well of $4 \mathrm{~mm}$ diameter was cut in a circle of 6 wells surrounding an internal well. The internal (middle) well was filled with a known serum of NDV and $\mathrm{H} 7$ while 
peripheral wells were filled with amnioallantoic fluid. After that, the plates were incubated at $37^{\circ} \mathrm{C}$ and observed every $24 \mathrm{hrs} \mathrm{till} 72 \mathrm{hrs}$. A line of precipitation was observed and noted.

\section{RNA Isolation}

The RNA was extracted by using TRIzol ${ }^{\circledR}$ reagent as per the manufacturer's protocol. Briefly, a volume of $250 \mu \mathrm{l}$ of tissue/fluid was mixed with $750 \mu$ l of $\mathrm{TRI}^{\circledR}$ reagent, centrifuged for $10 \mathrm{~min}$ at $10,000 \mathrm{rpm}$. The supernatant was mixed with $200 \mu$ l chloroform, incubated for $15 \mathrm{~min}$ and then centrifuged at $10,000 \mathrm{rpm}$ for $15 \mathrm{~min}$. After that, the supernatant was transferred to a sterilized Eppendorf, mixed with $500 \mu \mathrm{l}$ of chilled isopropanol and centrifuged for $10 \mathrm{~min}$ at $10,000 \mathrm{rpm}$. The upper fluid portion was discarded, and the RNA pellet was precipitated with ethanol $(100 \%)$. The RNA was diluted with $30 \mu \mathrm{l}$ of nuclease-free water and stored at $-80^{\circ} \mathrm{C}$ for further experimental analysis.

\section{Reverse Transcription Polymerase Chain Reaction (RT-PCR)}

It was performed through the Hot Start RT-PCR kit (Thermo Scientific) as per the manufacturer's protocol. A volume of $50 \mu \mathrm{l}$ of RT-PCR reaction mixture was prepared by mixing verso enzyme $(1 \mu \mathrm{l})$, master mix $(25 \mu \mathrm{l})$, RT enhancer $(2.5 \mu)$ ), forward primer $(1 \mu \mathrm{l})$, reverse primer

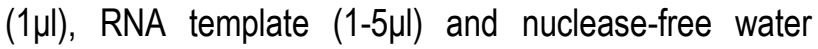
$(17 \mu \mathrm{l})$. The primers include $\mathrm{H} 7$-forward 5'CAGGCGGAATTGATAAGGAG 3' and H7 reverse 5' TGCCCCATTGAAACTGAAAG 3', and ND-forward 5' GGGAGGCATACAACAGGACA 3' and ND-reverse 5' TGGTTGCAGCAATGCTCTC 3'. The thermal cycling was carried at $45^{\circ} \mathrm{C}$ for $15 \mathrm{~min}$ ( 1 cycle for cDNA synthesis) with initial denaturation at $95^{\circ} \mathrm{C}$ for $15 \mathrm{~min}(1$ cycle). After that, 40 cycles including denaturation $\left(95^{\circ} \mathrm{C}\right.$ for $20 \mathrm{sec})$, annealing $\left(58^{\circ} \mathrm{C}\right.$ for $\left.30 \mathrm{sec}\right)$, extension $\left(72^{\circ} \mathrm{C}\right.$ for $1 \mathrm{~min}$.) and final extension $\left(72^{\circ} \mathrm{C} \text { for } 5 \mathrm{~min}\right)^{3}$ was performed.

\section{RESULTS}

In this study, the analysis of virus isolation of pooled $(n=200)$ samples has revealed that $116 / 200$ samples were found positive for various viruses, while $84 / 200$ samples were negative. Interestingly, the virus isolation test explored that the positive samples either contains
Newcastle disease virus (NDV), Avian influenza virus (H7 subtype) or co-infection caused by both NDV and H7N3 viruses as mentioned in Table 1.

Table 1. Prevalence of Different Viruses by Virus Isolation in Poultry at Karachi.

\begin{tabular}{cccc}
\hline S. No. & No. of Samples & HA Positive & HA Negative \\
\hline 01 & 200 & 116 & 84 \\
\hline
\end{tabular}

All samples with positive virus isolation were then subjected to an agar gel precipitation test for conformation. The analysis of results has found that NDV is most prevalent in the fields causing serious illness and occur in 50 samples out of 100, followed by mixed infections of Avian influenza virus ( $\mathrm{H} 7$ subtype) and NDV that occurs in 38 samples out of 100 , and then $\mathrm{H} 7$ subtype that was found positive in 8 samples out of 100 (Table 2).

Table 2. Prevalence of ND, H7 Subtype and ND+H7 Through Agar Gel Precipitation.

\begin{tabular}{ccccc}
\hline S. No. & $\begin{array}{c}\text { Type of } \\
\text { Infection }\end{array}$ & $\begin{array}{c}\text { No. of } \\
\text { Samples }\end{array}$ & $\begin{array}{c}\text { AGP } \\
\text { Positive }\end{array}$ & $\begin{array}{c}\% \text { of } \\
\text { Positive } \\
\text { samples }\end{array}$ \\
\hline 01 & NDV & 200 & 100 & 50 \\
\hline 02 & H7 Subtype & 200 & 16 & 08 \\
\hline 03 & NDV+H7N3 & 200 & 76 & 38 \\
\hline
\end{tabular}

After Agar gel precipitation, the samples were subjected to RT-PCR for a reliable diagnosis. The results of RTPCR have found that the Newcastle disease virus (NDV) was positive with clear bands at 238bp (Fig. 1).

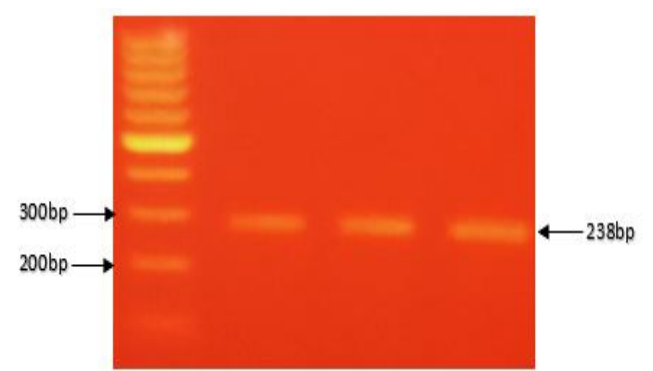

Figure 1. RT-PCR analysis of Newcastle disease virus (NDV). Lane 1 is DNA marker 100bp, Lane 2 positive control, Lane $3 \& 4$ = field sample. 
The results of RT-PCR have confirmed that the Avian influenza virus H7N3 subtype was circulating in local flocks that cause severe damage to poultry and found positive with expected product size 407bp (Fig. 2).

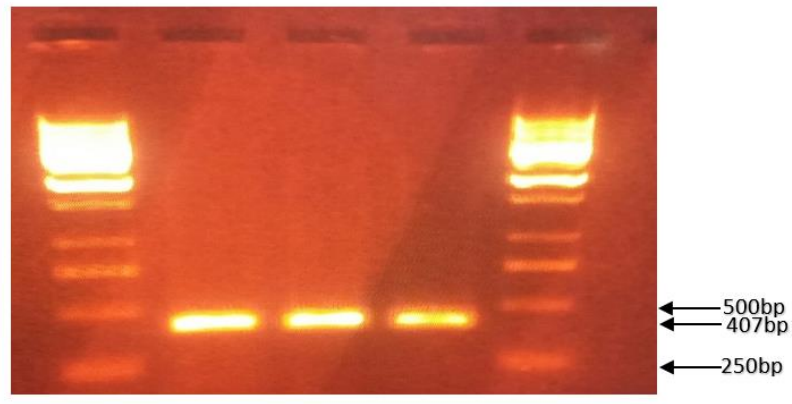

Figure 2. Amplification of NP gene of H7-subtype. An expected product size is $407 \mathrm{bp}$. Lane 1 \& 5 (DNA marker $1 \mathrm{~kb})$, Lane 2 = positive control, Lane $3 \& 4=$ field samples.

\section{DISCUSSION}

The poultry industry is an emerging and dynamic field in Pakistan. Despite this, poultry producers are facing problems such as the use of improper vaccination, medication and disposal of dead birds that may lead to the chance of infection, re-infection, dissemination of infectious agents and severe outbreaks of bacterial as well as viral diseases. Mixed infections of NDV and H7 cause heavy economic losses to the poultry industry. Therefore, this study was designed to know the prevalence of NDV and AIV (H7 subtype).

Virus isolation has revealed that most of the circulating viral pathogens in poultry in Sindh, Pakistan could be due to NDV and $\mathrm{H} 7$ subtype that have shown $58 \% \mathrm{HA}$ positive per 100 sample (Table 1). Similarly, the prevalence of $\mathrm{H} 9$ subtype in commercial poultry farms of Thatta, Karachi and Mirpurkhas districts of Sindh was found to be $97 \%$, $86 \%$ and $89 \%$, respectively, as compared to $31 \%, 41 \%$ and $53 \%$ for $\mathrm{H} 7 \mathrm{~N} 3$ subtype ${ }^{14}$. The high prevalence could be due to improper vaccination, disposal of dead birds and frequent mutation in these viruses. According to WHO, highly pathogenic AIV severely invaded poultry, transmit to humans, and caused 442 human cases leading to 262 deaths until September 2009 in Azerbaijan, Lao people's Democratic Republic, Thailand, Bangladesh, Myanmar, Nigeria, Pakistan, Cambodia, China, Djibouti, Egypt, Indonesia, Iraq, Turkey and Vietnam ${ }^{12}$.
Agar gel precipitation (AGP) revealed that out of $100 \%$ samples, $50 \%$ were found positive NDV (Table 2). Findings of the current study are in agreement with other findings, who have reported that the prevalence rate of Newcastle disease was comparatively higher in local breeds of birds i.e., $55.0 \%$ while it was found in layer, broiler and duck i.e.; $37.5 \%, 32.5 \%$ and $27.5 \%$, respectively 15 .

Results of the current study have found that the prevalence of mixed infection of NDV and $\mathrm{H} 7$ was $38 \%$ and $8 \%$ with $\mathrm{H} 7$ (Table 2). Correspondingly, others have reported that the prevalence of AIV in the live bird market was $23 \%{ }^{14}$. Similarly, it has been reported that infections of the Avian influenza virus and Newcastle disease virus have been increased in Pakistan in the last few decades ${ }^{15,16}$. Likewise, the outbreaks of the Avian influenza virus (H7N3) in Pakistan during 2003 caused the death of 3.2 million birds ${ }^{17}$. The reason for the higher prevalence of AIV might be either the transportation of birds from the local market to the urban areas or due to the improper vaccination and disposal of dead birds. Moreover, the zoonotic infections caused by Avian influenza viruses such as H5NX, H7NX, H9N2 and H10N8 are sporadically detected $18,19,20$. The pathogenicity of Avian influenza virus $\mathrm{H} 7$ Subtype is associated with polybasic cleavage site i-e, PEKRRKR/G at position 322 to 329 amino acids ${ }^{21}$.

The RT-PCR have shown that NDV was positive with the clear band at 238bp, similarly, the $\mathrm{H} 7$ virus is positive with 409bp (Fig. 1 \& 2). The primer set tested in this research work might show homogeneity endemic nature of circulating virus in Pakistan ${ }^{17}$. The increasing outbreaks either be due to migratory birds, exotic birds or imported vaccines.

\section{CONCLUSION}

It is concluded that the NDV and H7N3 are circulating in the poultry flocks causing co-infections. However, the rate of co-infections of NDV and H7N3 is highest followed by the Newcastle disease virus. Therefore, it is important to isolate the circulating strains of NDV and $\mathrm{H} 7$ subtypes to prepare vaccines such as monovalent NDV/H7N3, divalent NDV+H7N3 or polyvalent IBV+NDV+AIV to get rid of emerging infections and heavy economic losses. 


\section{ACKNOWLEDGEMENTS}

We are highly thankful to the DG/ Executive director of Sindh Institute of Animal Health Karachi, for his kind support and gratitude.

\section{LIST OF ABBREVIATIONS}

AGP Agar Gel Precipitation

AIV Avian Influenza Virus

HA Hemagglutination Assay

HPAIVs Highly Pathogenic Avian Influenza Viruses

NDV Newcastle Disease Virus

RT-PCR Reverse Transcription Polymerase

Chain Reaction

VI Virus Isolation

\section{REFERENCES}

1. GOP. Pakistan Economic Survey. Economic Affair Division. Government of Pakistan, Islamabad. 2014.

2. GOP. Pakistan Economic Survey. Economic Affair Division. Government of Pakistan, Islamabad. 2016.

3. Ahmed A, Khan TA, Kanwal B, Raza Y, Akram M, Rehmani SF et al. Molecular identification of agents causing respiratory infections in chickens from southern region of Pakistan from October 2007 to February 2008. Int J Agric Biol. 2009; 11:325-8.

4. Swayne DE. (ed.), A laboratory manual for the isolation and identification of Avian pathogens, $4^{\text {th }}$ edition American Association of Avian Pathologists, Kennett Square, PA. p. 150-5.

5. Muhammad K, Rabbi F, Hussain I, Riaz A, Saeed K, Hussain T. Passive immunization against Infectious Bursal Disease in chicks. Int J Agric Biol. 2001; 3:413-5.

6. Yashpal SM, Devi PP, Sagar MG. Detection of three avian respiratory viruses by single-tube multiplex reverse transcription polymerase chain reaction assay. J Vet Diagn Invest. 2004; 16:244-8.

7. Sarwar MG, Muhammad K, Rabbani M, Younus M, Sarwar N, Ali MA et al. Prevalence of avian influenza viruses in live bird markets of Lahore. J Ani \& Plan Sci. 2013; 23(2):388-92
8. Numan M, Siddique M, Ashraf M, Khan HA, Yousaf MS. Quantification of antibodies against avian influenza virus subtype H7N3 in layer flocks in central Punjab (Pakistan). Int J Agric Biol. 2005; 7:564-6.

9. Chen H, Y Li, Z Li, Shi J, Shinya K, Deng G et al. Properties and dissemination of $\mathrm{H} 5 \mathrm{~N} 1$ viruses isolated during an influenza outbreak in migratory waterfowl in Western China. J Virol. 2006; 80:597683.

10. Kida $\mathrm{H}$. Ecology of influenza viruses in nature, birds, and humans. Global Environmental Research. Assoc. of International Research Initiatives for Environmental Studies. 2008; 12:9-14.

11. Peiris MJS, de Jong MD, Guan Y. Avian influenza virus (H5N1): A threat to human health. Clin Microbiol Rev. 2007; 20(2):243-67.

12. Munster VJ, Wallensten A, Baas C, Rimmelzwaan GF, Schutten M, Olsen B et al. Mallards and highly pathogenic avian influenza ancestral viruses, Northern Europe Emerg Infect Dis. 2005; 11:1545-51.

13. Okwor EC, Eze1 DC, Okonkwo KE, Ibu JO. Comparative evaluation of agar gel precipitation test (AGPT) and indirect hemagglutination test (IHA) for the detection of antibodies against infectious bursal disease (IBD) virus in village chickens. African $\mathrm{J}$ Biotech. 2011; 10(71):16024-7.

14. Shahab A. Isolation, identification, and pathogenicity of field strains of avian influenza viruses prevalent in commercial and backyard poultry. Department of Veterinary Pathology, Sindh Agriculture University Tandojam. 2016. p. 1-75.

15. Capua I, Cancellotti FM. Newcastle disease and avian influenza in Italy during 1999 and 2000. Selezione-Veterinaria. 2000; 11:971-2.

16. Negovetich NJ, Feeroz MM, Jones-Engel L, Walker D, Alam SM. Live bird markets of Bangladesh: H9N2 viruses and the near absence of highly pathogenic H5N1 influenza. PLoS One. 2011; 6:193-211.

17. Spackman E, Jr Jack Gelb, Lauren PA, Brian SL, Conrad RP, Pantin-Jackwood MJ et al. The pathogenesis of low pathogenicity $\mathrm{H} 7$ avian influenza viruses in chicken, ducks, and turkeys. Virol J 2010; 7:331-41.

18. Harris KA, Freidl GS, Munoz OS, Von DS, De Nardi M, Wieland B, Koopmans MPG et al. Epidemiological risk factors for animal influenza $A$ viruses overcoming species barriers. Ecohealth. 2017. 14 (2), 342-60. 
19. Imai M, Watanabe T, Kiso M, Nakajima N, Yamayoshi $\mathrm{S}$, Iwatsuki-Horimoto $\mathrm{K}$, et al. A highly pathogenic avian $\mathrm{H} 7 \mathrm{~N} 9$ influenza virus isolated from $A$ human is lethal in some ferrets infected via respiratory droplets. Cell Host Microbe. 2017; 615-26.

20. Irina IS, Daniil K, Tatiana S, Tatiana K, Svetlana D, Victoria $\mathrm{M}$, et al. Broadly protective anti-hemagglutinin stalk antibodies induced by live attenuated influenza vaccine expressing chimeric hemagglutinin. Virol $\mathrm{J}$. 2018; 313-23.
21. Gischke $M$, Ulrich $R$, I Fatola $O$, Scheibner $D$, Salaheldin AH, Crossley B, et al. Insertion of basic amino acids in the hemagglutinin cleavage site of H4N2 avian influenza virus (AIV)-reduced virus fitness in chickens is restored by reassortment with highly pathogenic H5N1 AIV. Int J Mol Sci. 2020; 21(7): 23-53. 